\title{
Флористическое разнообразие лесных сообществ низкогорий Кузнецкого Алатау (Кемеровская область)
}

\section{Floristic diversity of forest communities in the lowlands of Kuznetsk Alatau (Kemerovo region)}

\author{
Хрусталева И. А., Стрельникова Т. О., Куприянов О. А., Куприянов А. Н., Манаков Ю. А. \\ Khrustaleva I. A., Strelnikova T. O., Kupriyanov O. A., Kupriyanov A. N., Manakov Yu. A. \\ Кузбасский ботанический сад, Федеральный исследовательский центр угля и углехимии СО РАН, г. Кемерово, Россия. \\ E-mail: atriplex@rambler.ru
}

Kuzbass botanical garden, The Federal Research Center of Coal and Coal Chemistry SB RAS, Kemerovo, Russia

\begin{abstract}
Peфepam. Приведены результаты исследований лесных сообществ низкогорий Кузнецкого Алатау (Кемеровская область). Выявлено флористическое разнообразие пяти участков, расположенных в трех ботанико-географических районах: Барзасского таежного, Томь-Кондомского предгорного и Кузнецко-Алатаусского высокогорного. На обследованных участках были отмечены растения, включенные в Красную книгу Кемеровской области (2012): Asarum europaeum L., Dactylorhiza fuchsii (Druce) Soa, Erythronium sibiricum (Fisch. et C.A. Mey.) Krylov, Polypodium vulgare L., Sanicula europaea L., Tilia sibirica Bayer.
\end{abstract}

Ключевые слова. Кузнецкий Алатау, лесные сообщества, редкие виды, флора, флористическое богатство.

Summary. The results of studies of forest communities in the lowlands of the Kuznetsk Alatau (Kemerovo region) are presented. The floristic diversity of five sites located in three botanical and geographical areas: the Barzassky taiga, Tom-Kondomsky foothill and Kuznetsk-Alataus high-mountainous areas was revealed. In the surveyed areas, the plants included in the Red Book of the Kemerovo Region (2012) were noted: Asarum europaeum L., Dactylorhiza fuchsii (Druce) Soa, Erythronium sibiricum (Fisch. et C.A. Mey.) Krylov, Polypodium vulgare L., Sanicula europaea L., Tilia sibirica Bayer.

Key words. Flora, floristic wealth, forest communities, Kuznetsk Alatau, rare species.

Интенсивное хозяйственное освоение приводит к трансформации растительного покрова и потере биологического разнообразия. Эти процессы проявляются особенно резко в горнодобывающих регионах, в том числе и в Кемеровской области, так как здесь сосредоточены основные запасы Кузнецкого угольного бассейна. В низкогорных лесных ландшафтах Кузнецкого Алатау интенсивно разрабатываются месторождения угля, а также золотоносные, сосредоточенные в долинах малых рек. Эта деятельность связана с полной трансформацией растительного покрова и приводит к уничтожению исходных растительных сообществ.

Господствующим типом растительности на данных территориях является темнохвойная тайга - элемент коренной растительности Западной Сибири (Ермаков, 2003). Многими исследователями отмечаются характерные признаки, которые можно суммировать следующим образом: черневые леса распространены в районах с повышенной теплообеспеченностью и влажностью климата; в древостое преобладает пихта и осина; присутствуют крупные кустарники, не образующие самостоятельного яруса; развитие высокотравья из цветковых растений и папоротников, под пологом которого нередко произрастают таежные тенелюбивые растения; присутствие в травостое неморальных реликтов; мощное развитие синузии весенних эфемероидов; слабая роль или полное отсутствие синузии напочвенных листостебельных мхов (Эбель, 2012). 
Для оценки флористического разнообразия использованы материалы полевых исследований 2018 г., выполненных на пяти участках в низкогорных ландшафтах Кузнецкого Алатау. Исследованные участки расположены в низкогорьях Кузнецкого Алатау, на территории трех геоботанических районов (Куминова, 1950): Барзасского таежного, Томь-Кондомского предгорного и Кузнецко-Алатаусского высокогорного (в северной низкогорной части). Участки Чениговец и Кыргай примыкают к уже действующим угледобывающим разрезам, участки Сисим и Кундат будут разрабатываться золотодобытчиками, участок Кундель используется как охотничье хозяйство. Все участки довольно однородны по строению - пологие склоны, небольшие ручьи и речки, основную площадь занимают темнохвойные леса или их производные. Все участки несут следы хозяйственной деятельности человека - это сеть лесных дорог и просек, старые вырубки и гари, на некоторых участках имеются территории с полностью измененным растительным покровом - технологические дороги, промплощадки, отвалы, старые дражные отвалы. Характеристика участков приведена в таблице.

На каждом исследованном участке учитывались все виды высших сосудистых растений, выполнено 226 геоботанических описаний. На основании геоботанических описаний были выделены типы растительных группировок. Для каждого типа составлен флористический список (табл.).

Таблица

Характеристика исследованных участков

\begin{tabular}{|c|c|c|c|c|c|}
\hline $\begin{array}{l}\text { Геоботанический район } \\
\text { (Куминова, 1950) }\end{array}$ & $\begin{array}{l}\text { Барзасский } \\
\text { таежный }\end{array}$ & \multicolumn{2}{|c|}{$\begin{array}{l}\text { Томь-Кондомский } \\
\text { предгорный }\end{array}$} & \multicolumn{2}{|c|}{$\begin{array}{c}\text { Кузнецко-Алатаусский } \\
\text { высокогорный }\end{array}$} \\
\hline Название участка & Черниговец & Кыргай & Кундель & Кундат & Сисим \\
\hline Площадь, га & 429 & 1577 & 1922 & 120 & 3988 \\
\hline Высота наду.м., м & $172-421$ & $295-363$ & $685-706$ & $510-547$ & $467-568$ \\
\hline Кол-во описаний & 67 & 44 & 30 & 44 & 41 \\
\hline $\begin{array}{l}\text { Всего видов, } \\
\text { в том числе: }\end{array}$ & 163 & 166 & 207 & 200 & 155 \\
\hline $\begin{array}{l}\text { Пихтовые или осиново-пихтовые } \\
\text { леса с мелкотравьем }\end{array}$ & 102 & 60 & 109 & 69 & 60 \\
\hline $\begin{array}{l}\text { Пихтовые или осиново-пихтовые } \\
\text { леса с мелкотравьем сырые }\end{array}$ & & 84 & & & \\
\hline $\begin{array}{l}\text { Пихтовые и пихтово-осиновые } \\
\text { высокотравные леса }\end{array}$ & 81 & 61 & 90 & 79 & 69 \\
\hline $\begin{array}{l}\text { Березовые и пихтово-березовые } \\
\text { леса заболоченные }\end{array}$ & 43 & & & 84 & 74 \\
\hline Прогалины и поляны & 52 & 89 & 10 & & 44 \\
\hline $\begin{array}{l}\text { Высокотравные сообщества по } \\
\text { берегам рек и ручьев }\end{array}$ & & & & 62 & 53 \\
\hline $\begin{array}{l}\text { Заросли кустарников по берегам рек } \\
\text { и ручьев }\end{array}$ & 39 & 68 & 101 & 107 & 27 \\
\hline Болота & & & & 31 & 44 \\
\hline Скалы & & & 76 & & 62 \\
\hline Вырубки и гари & 43 & 87 & 35 & 60 & \\
\hline Лесные дороги & 24 & 82 & 70 & 58 & 51 \\
\hline Нарушенные местообитания & 96 & & & 28 & 31 \\
\hline \multicolumn{6}{|l|}{ Жизненная форма } \\
\hline Древесные & 7 & 5 & 6 & 5 & 5 \\
\hline Кустарниковые & 18 & 17 & 19 & 15 & 14 \\
\hline Травянистые & 138 & 144 & 182 & 180 & 134 \\
\hline
\end{tabular}

Флористическое богатство каждого участка невелико и насчитывает от 155 до 200 видов высших сосудистых растений. Исследованные лесные сообщества отличаются стабильным составом слагающих их древесных и кустарниковых видов. Всего на участках отмечено 10 видов деревьев и 25 ви- 
дов кустарников. Основные лесообразующие породы - пихта (Abies sibirica Ledeb.) и осина (Populus tremula L.), довольно часто встречается береза (Betula pendula Roth), в редких случаях кедр (Pinus sibirica Du Tour.). По берегам речек и ручьев, по сырым понижениям добавляются береза пушистая (Betula pubescens Ehrh.) и ель сибирская (Picea obovata Ledeb.). Для участка Кундель характерно присутствие липы сибирской (Tilia sibirica Bayer). На нарушенных местообитания чаще встречаются Pinus sylvestris L., Populus nigra L., а также адвентивный Acer negundo L.

Кустарники, встречающиеся на исследованных участках, также имеют стабильный состав. В составе подлеска обычны Padus avium Mill. и Sorbus sibirica Hedl., Sambucus sibirica Nakai, Caragana arborescens Lam. Нижний кустарниковый ярус образуют Ribes atropurpureum C.A.Mey., R. nigrumL., Rubus idaeus L., Lonicera xylosteum L., Spiraea media Schmidt, Viburnum opulus L. Изредка встречаются Crataegus sanguine Pall., Daphne mezereum L. На опушках и прогалинах отмечались Ribes hispidulum (Jancz.) Pojark., Rosa majalis Herrm. По сырым понижениям и берегам речек и ручьев обычны ивовые заросли из Salix dasyclados Wimm., S. viminalis L., S. caprea L., S. cinerea L., S. rorida Laksch., S. triandra L. Только на участке Кундель встречаются Caragana frutex (L.) K. Koch и Cotoneaster melanocarpus Fisch. ex Blytt. Из адвентивных видов отмечена только облепиха (Hippophae rhamnoides L.), разрастающаяся на отвалах на участке Черниговец.

Отличия во флоре на разных участках формируются за счет травянистых видов. Их число колеблется от 134 (Сисим) до 182 видов (Кундель). Число видов растений в данном случае слабо растет с увеличением обследованной площади. Так, в бассейне р. Большой Теш встречается 514 видов на площади 257 км кв. На участке Кундель, имеющем значительно меньшую площадь (около 7 \% от площади бассейна), произрастает 207 видов (около 40 \% видов флоры бассейна). Для бассейна р. Б. Промышленная, занимающего площадь 568 км кв., приводится 499 видов (Шереметов, Шереметова, 2018). Флора участка Черниговец площадью 429 га (0,8 \% площади бассейна р. Б. Промышленная) насчитывает 163 вида (33\% от состава флоры бассейна). Флористический состав даже таких небольших участков можно считать достаточно представительным для таежных низкогорий Кузнецкого Алатау.

Максимальным числом видов отличаются пихтовые или осиново-пихтовые леса с преобладанием в травянистом покрове видов таежного мелкотравья на участках Черниговец и Кундель, пихтовые и пихтово-осиновые высокотравные леса на всех исследованных участках (флористические списки содержат 60-90 видов). Значительным флористическим разнообразием отличаются кустарниковые заросли по берегам рек и ручьев на участках Кундель и Кундат, поляны и прогалины и вторичные лесные сообщества на участке Кыргай. Нужно отметить, что таежные сообщества и их производные отличаются постоянным набором видов и не столько отличаются друг от друга флористическим составом, сколько ролью отдельных видов. Виды высокотравья Calamagrostis purpurea (Trin.) Trin., Milium effusum L., Urtica dioica L., Angelica sylvestris L., Veratrum lobelianum Bernh., Heracleum dissectum Ledeb., Jacobaea nemorensis (L.) E. Wiebe, папоротники - Athyrium filix-femina (L.) Roth, Dryopteris filix-mas (L.) Schott. довольно часто встречаются единичными экземплярами под густым пологом пихтовых лесов, а низкотравные таежные виды и эфемероиды Oxalis acetosella L., Stellaria bungeana Fenzl, Myosotis krylovii Serg., Corydalis bracteata (Steph.) Pers., Ranunculus monophyllus Ovcz., Allium microdictyon Prokh., Viola uniflora L., Anemonoides caerulea (DC.) Holub, Adoxa moschatellina L., Erythronium sibiricum (Fisch. et C.A. Mey.) Krylov образуют нижний ярус в сообществах высокотравных лесов и полян.

Некоторой оригинальностью флористического состава отличаются таежные сообщества на участке Кундат, где встречаются пихтовые и березово-пихтовые леса с черникой, занимающие понижения в рельефе, с высоким уровнем стояния грунтовых вод, или выходом ключей на дневную поверхность. Таежные сообщества на участке Кундель также имеют оригинальные элементы - в древесном ярусе встречается Tilia sibirica Bayer, а в травянистом отмечался подлесник европейский (Sanicula europaea L.).

Вклад во флористический состав участков Кундель и Сисим вносят особые местообитания скальные выходы. Карбонатные скалы на участке Сисим описаны в долине р. Известковой. Высота скал 3-5 метров, вершины заняты лесными ценозами с участием пихты, ели, кедра, березы. На склонах с мелкоземом и в трещинах скал растут кустарники. Специфическими являются виды петрофиты Sedum hybridum L., Woodsia ilvensis (L.) R. Br. На участке Кундель на скальных выходах отмечены Ade- 
nophora liliifolia (L.) A. DC., Galium verum L., Hieracium virosum Pall., Hylotelephium ewersii (Ledeb.) H. Ohba, Polypodium vulgare L.

Околоводные сообщества занимают небольшие площади на всех исследованных участках. Растительный покров околоводных местообитаний представлен лесными древесными и травянистыми видами, образующими заболоченные осиновые и березово-ивовые леса. По берегам водотоков и озер, как правило, имеющих заболоченные берега, формируются ивовые и травянистые сообщества. Доминантами кустарниковых сообществ являются Salix viminalis и $S$. dasyclados. В травянистых околоводных сообществах доминируют Typha angustifolia L., Phragmites australis (Cav.) Trin. ex Steud. или представители семейства осоковых - Scirpus sylvaticus L., Carex vesicaria L., Eleocharis palustris (L.) Roem. \& Schult. Обычными видами на сырых заболоченных лугах являются Equisetum fluviatile L., Lycopus europaeus L., Cirsium setosum (Willd.) Besser, Rorippa palustris (L.) Besser, Veronica serpyllifolia L. Даeт ярко-желтый весенний аспект Caltha palustris L., значительный процент проективного покрытие имеет Filipendula ulmaria (L.) Maxim.

Безусловно, нарушенные местообитания (технологические дороги, промплощадки, отвалы, старые дражные отвалы, зарастающие единично деревьями и кустарниками) вносят свой вклад во флористический состав каждого участка. Лесные дороги и просеки по обочинам зарастают как типичными лесными видами - Paeonia anomala L., Pteridium aquilinum (L.) Kuhn, Aegopodium podagraria L., Crepis sibirica L., Milium effusum, так и сорными - Plantago major L., Poa supina Schrad.), Androsace septentrionalis L. Проезжие дороги являются путями, по которым в лесные сообщества проникают рудеральные антропофильные виды. Часто встречаются сорные апофиты - Capsella bursa-pastoris (L.) Medikus, Artemisia sieversiana Willd., Arctium lappa L., Cirsium setosum, Taraxacum officinale F.H. Wigg., Galeopsis bifida Boenn. В составе адвентивных растений - Amoria hybrida (L.) C. Presl, Tripleurospermum inodorum (L.) Sch. Bip.

Максимальное число видов на нарушенных местообитаниях зафиксировано на участке Черниговец, который примыкает к уже нарушенным угледобычей территориям, здесь проходит технологическая дорога, и сеть лесных дорог и просек очень густая. Семязачатки попадают с окрестных отвалов, по дорогам, на колесах автотранспорта, со строительным материалом. Здесь отмечены чужеродные древесные виды -Hippophae rhamnoides, Acer negundo, расселяющиеся самостоятельно из посадок на отвалах или пришахтовых территорий. Лесные травянистые виды представлены значительным числом, но очень низким обилием (обычно единично) - Anthriscus sylvestris (L.) Hoffm., Heracleum dissectum, Glechoma hederaceaL., Stachys sylvatica L. С высоким обилием представлены отдельные виды -Tussilago farfara L., Chamaenerion angustifolium (L.) Scop., Urtica dioica. На нарушенных местообитаниях наиболее часто и обильно разрастаются сорные виды растений - Chenopodium album L., Picris hieracioides L., Sonchus arvensis L.; в том числе адвентивные-Pastinaca sylvestris Mill., Cirsium vulgare (Savi) Ten.

Старые дражные отвалы на участках Сисим и Кундат, зарастающие единично деревьями и кустарниками, не имеют сомкнутого древесного полога. Salix rorida может занимать до 30 \% площади. Видами с высокой численностью являются Calamagrostis obtusata Trin., Bupleurum longifolium L., Heracleum dissectum; сорные и асоциальные виды - Amoria repens (L.) C. Presl, Chamaenerion angustifolium.

На обследованных участках были отмечены растения, включенные в Красную книгу Кемеровской области (2012). Единственный вид, встречающийся в большом обилии в таежных местообитаниях, - Erythronium sibiricum. На участке Кундель отмечено максимальное число таких редких видов: Polypodium vulgare, Dactylorhiza fuchsii, Sanicula europaea, Tilia sibirica, Asarum europaeum. Последний вид отмечен так же на участке Кыргай.

Таким образом, флористический состав небольших по площади участков в таежных ландшафтах Кузнецкого Алатау содержит 30-40 \% видов флоры более крупных естественных выделов, таких как речной бассейн. Флористический состав таежных сообществ стабилен на значительном протяжении и обогащается за счет видов каменистых выходов, болотных и антропофильных. Редкие и нуждающиеся в охране виды отмечены на всех исследованных участках. Только Erythronium sibiricum обилен и широко распространен в таежных ценозах, остальные виды встречаются редко и с невысоким обилием. 
Работа выполнена в рамках государственного задания «Оценка состояния и охрана флористического разнообразия под влиянием антропогенных и техногенных факторов insitu и exsitu» № 0352-20190015; № госрегистрации AAAA-A17-117041410053-1. Гербарные сборы хранятся в УНУ Гербарий Кузбасского ботанического сада (KUZ).

\section{ЛИТЕРАТУРА}

Ермаков Н. Б. Разнообразие бореальной растительности Северной Азии. Континентальные гемибореальные леса. Классификация и ординация. - Новосибирск: Изд-во СО РАН, 2003. - 232 с.

Красная книга Кемеровской области: Редкие и находящиеся под угрозой исчезновения виды растений и грибов. Т. 1. - Кемерово: Азия-принт, 2012. - 208 с.

Куминова А. В. Растительность Кемеровской области. - Новосибирск, 1950. - 167 с.

Шереметов P. T., Шереметова С. А. Влияние морфологических особенностей речных бассейнов на таксономическое богатство флоры // Проблемы промышленной ботаники индустриально развитых регионов: Сб. материалов докладов V междунар. конф. (2-3 октября 2018 г., Кемерово). - Кемерово, 2018. - С. 123-125.

Эбель А. Л. Конспект флоры северо-западной части Алтае-Саянской провинции. - Кемерово: КРЭОО Ирбис, 2012. $-568 \mathrm{c}$. 